\title{
LITERATURE
}

\author{
DOI https://doi.org/10.30525/978-9934-26-039-1-18
}

\section{TROUGH EMBLEMS TO METAPHYSICAL WIT: CREATING THE ART OF INGENUITY}

\author{
Bezrukov A. V. \\ Candidate of Philological Sciences, \\ Assistant Professor at Philology and Translation Department \\ Dnipro National University of Railway Transport \\ named after Academician V. Lazarian \\ Dnipro, Ukraine
}

To begin with, it does make sense to distinguish the concepts of metaphysical poetry, which covers Baroque literature, and the metaphysical tradition, which extends to world literature. This approach is aimed not only at simplifying the research of extremely heterogeneous metaphysical poetry, but it also provides a closer look at the works of the Metaphysical school's pioneers since it was their works established the style called metaphysical. Metaphysical poetry is a new spiritual meaning of the language, which was brought beyond the specificity and unambiguity of a phrase, as well as the ability to combine unrelated objects and phenomena through emblems and symbols (Locke, 2018).

The study of issues of linguistic and visual representation of emblems in the seventeenth-century English metaphysical poetry demonstrates the character of using the emblem in the poetic discourse of Baroque literature, the ways of expressing an emblematic component in the artistic practices of the Metaphysicals. Emblems are considered a key element of the creative method of metaphysical poets. The figurative and symbolic dimension of a poem is inextricably linked to the author's messages and intentions; it is construed as one of the means of updating the cultural patterns of literature.

Studying metaphysical poetry in this problematic field is intended to demonstrate the attitude of the poets of the Metaphysical school to the cultural and historical events of that time, manifesting in the sophisticated emblems, which form an artistic vision of metaphysical poets and clearly distinguish their works among the other famous authors. The emblem, becoming both a way and a means of artistic thinking of the Baroque period, the key to the allegorical representation of reality / mysterious signs of being, appears to be a 
distinctive feature of the Metaphysical school in England. Through the use of artistic potencies of the emblem, the Metaphysicals sought to change the surrounding reality.

John Donne, the acknowledged leader of the Metaphysical school, preeminent English poet, has acquired a reputation as one of the most controversial authors in the history of English literature due to intellectualism of poetry (wit), which, in particular, is achieved by turning to the allegorical method of poeticizing. Literary criticism defines the creative method of Donne as the aesthetics of fragmentation (Grady, 2017), meaning the turn from the unity of artistic dimensions to their fragmentation.

Wit in metaphysical poetry allowed for involving different allegorical means and following mysterious signs of life. Wit was a new model of the Metaphysicals' thinking; it contributed to the formation of the imagery in the metaphysical works that presented the object of new experience. Wit and metaphysics formed a holistic system of poetic expressions, poetic texts being regulated by conceit, the widespread use of which distinguished Donne's and the Metaphysicals' works among the poets of the previous generation (Metaphysical Conceit, 2016). Metaphysical wit extended the potency for the manifestation of artistic imagination; the combination of the poetic, scientific, and religious presented such a projection as a figurative perception of various spheres of human existence, based on the idea of the unbounded capabilities of artistic imagination.

The spirit and imagery of Donne's poetry had a serious impact on English literature. The school of poets of the mid-seventeenth century, associated with Donne's influence, sometimes is even called the school of wit. This name came from the tendency common in those years to introduce witty and intricate paradoxes, emblems, witticisms into poetry, to build poems as extended metaphors. But metaphysical wit is essentially different from other modes of wit current in Renaissance Europe (Smith, 1992).

A system of images, symbols, and signs, which require being determined, objectifies a specific attitude to the comprehension of the sacred origin of the universe. Wit in the poetry, manifesting itself at all the levels of imaginary, serves as an artistic basis for reconstructing the metaphysical worldview and creating the art of ingenuity.

Metaphysical poetry, in which the supernatural essence of being and transpersonal experience take an art form (Bezrukov, 2020, p. 375), is still a matter of current interest for literary studies that attempt to come closer to comprehension wit through emblems in metaphysical poetry. It remains open to new creative and formal dimensions of the world literary process. 


\title{
References:
}

1. Bezrukov, A. (2020). Transformation and interpretation of gender concepts in metaphysical dimension: From contemplative worldview to transpersonal experience. Humanities \& Social Sciences Reviews, 8(4), 373-381. https://doi.org/10.18510/hssr.2020.8437.

2. Grady, H. (2017). John Donne and Baroque allegory: The aesthetics of fragmentation. Cambridge University Press. https://doi.org/10.1017/ 9781108164337.

3. Locke, J. D. (2018). Images and image symbolism in metaphysical poetry with special reference to other-worldliness. Van Duuren Media.

4. Metaphysical conceit: Element of metaphysical poetry. (2016, December 25). Moelancholy. https://moelancholy.wordpress.com/2016/ 12/25/metaphysical-conceit.

5. Smith, A. J. (1992). Metaphysical wit. Cambridge University Press. https://doi.org/10.1017/CBO9780511553394

DOI https://doi.org/10.30525/978-9934-26-039-1-19

\section{ЖАНРОВЫЕ УСЛОВИЯ ВОСПРИЯТИЯ ВЕРТИКАЛЬНОГО КОНТЕКСТА (ШРИФТ)}

\author{
Дудников Н. А. \\ кандидат филологических наук, доцент, \\ доиент кафедри перевода и славянской филологии \\ Криворожского государственного педагогического университета \\ 2. Кривой Рог, Днепропетровская область, Украина
}

Мохначева О. В.

кандидат филологических наук, доиент, доцент кафедри перевода и славянской филологии Криворожского державного педагогічного университета г. Кривой Рог, Днепропетровская область, Украина

В современной литературоведческой ситуации все большее значение приобретает понятие «текст» как основной предмет исследования, а также связанные с ним парадигмы «контекст», «паратекст», «гипертекст» и пр. Интерес к функциям этих элементов художественного произведения обусловлен активной разработкой ключевой категории эстетики постмодернизма «мир как текст» (Ж. Деррида) и во многом 76 